\title{
Variability of Microwave Radio Refractivity and Field Strength over Some Selected Locations in Nigeria
}

\author{
Adekunle Titus Adediji ${ }^{1}$, Samuel Oluwadare Adebusola ${ }^{1^{*}}$ \\ and Joseph Sunday Ojo ${ }^{1}$ \\ ${ }^{1}$ Department of Physics, Federal University of Technology, Akure, Nigeria.
}

Authors' contributions

This work was carried out in collaboration between all authors. Author ATA designed the study. Author SOA performed the statistical analysis, wrote the protocol, wrote the first draft of the manuscript and also managed the literature searches. Author JSO managed the analyses of the study. All authors read and approved the final manuscript.

Article Information

DOI: $10.9734 / \mathrm{PSIJ} / 2017 / 33447$ Editor(s):

(1) Aleksey Anatolievich Zakharenko, The International Institute of Zakharenko Waves (IIZWs), Krasnoyarsk, Siberia, Russia. (2) Christian Brosseau, Distinguished Professor, Department of Physics, Université de Bretagne Occidentale, France. Reviewers:

(1) Ugwu, Ernest Benjamin Ikechukwu, University of Nigeria, Nsukka, Nigeria.

(2) Yong Gan, California State Polytechnic University, Pomona, USA. (3) Aruna Prabhakar Maharolkar, Marathwada Institute of Technology, India. Complete Peer review History: http://www.sciencedomain.org/abstract/19063

Original Research Article

Received $15^{\text {th }}$ April 2017

Accepted $5^{\text {th }}$ May 2017

Published $15^{\text {th }}$ May 2017

\section{ABSTRACT}

In this study, results of the variation of radio field strength derived from the computation of surface refractivity through measurements of temperature, relative humidity and pressure across seven locations ((Akure $\left(7.15^{\circ} \mathrm{N}, 5.12^{\circ} \mathrm{E}\right)$, Lagos $\left(6.30^{\circ} \mathrm{N}, 3.20^{\circ} \mathrm{E}\right)$, Abuja $\left(7.10^{\circ} \mathrm{N}, 9.25^{\circ} \mathrm{E}\right)$, Jos $\left(9.50^{\circ} \mathrm{N}\right.$, $\left.8.50^{\circ} \mathrm{E}\right)$, Makurdi $\left(7.30^{\circ} \mathrm{N}, 8.53^{\circ} \mathrm{E}\right)$, Port-Harcourt $\left(4.20^{\circ} \mathrm{N}, 7.00^{\circ} \mathrm{E}\right)$, and Nsukka $\left(6.90^{\circ} \mathrm{N}, 7.67^{\circ} \mathrm{E}\right)$ ) in Nigeria are presented. Two years (Jan., 2011-Dec., 2012) archived data as provided by Tropospheric Data Acquisition Network (TRODAN) of the Centre for Atmospheric Research, Anyigba, Kogi State were utilized for the study. Results showed that the values of surface refractivity $\left(N_{s}\right)$ were low during the dry season months and high during the wet season months and also there was high values of $N_{S}$ at the coastal areas compared with the inland areas. It was also deduced that the average value of $N_{S}$ for Abuja, Akure, Jos, Lagos, Markurdi, Nsukka and PortHarcourt is $355,362,303,391,375,361$ and $399 \mathrm{~N}$-units respectively. Also the average values of Field Strength Variability (FSV) are 30.38, 20.16, 21.39, 24.21, 24.31, 21.49, and $21.48 \mathrm{~dB}$ in the respective locations and that the FSV values were high during the dry season months and low

*Corresponding author: E-mail: samueldarrey@gmail.com, samueldarrey@yahoo.com; 
during the wet season months. This may be attributed to the prevalence of high temperature during dry season and low temperature during the wet season.

Keywords: Microwave; radio refractivity; radio field strength; troposphere; telecommunication.

\section{INTRODUCTION}

Communication is the process of conveying information through the exchange of thoughts, messages, speech, visuals, signals, writing, or b ehaviour. It is the meaningful exchange of inform ation between a source and a receiver. Basically, a message is sent from the source through a medium to the receiver. Radio wave propagation is the sending out of electromagnetic energy from a transmitter to a receiver and it is affected by the rate of change of the radio refractivity, $N$ with altitude in the troposphere [1,2]. The propagation environment is the geographical area over which the wave spreads between a transmitter and a receiver. However, how far a radio signal will travel within the radio horizon is determined by the distribution of the radio refracti vity. Mobile communication systems employ the microwave frequency bands because of its broad bandwidth $[2,3]$. In radio frequency telecommunic ations, field strength is the magnitude of the received electromagnetic field which will excite a receiving antenna and thereby induce a voltage at a specific frequency in order to provide an input signal to a radio receiver. In designing a wireless communication system, the spatial and diurnal variation of radio refractive index is important [4]. In wireless network planning and optimization, radio wave propagation prediction modelling is an important tool [5]. Field strength meters are used for such applications as cellular, broadcasting, Wi-Fi and a wide variety of other radio related applications. Several researchers have studied electromagnetic wave (EMW) medium interaction processes and the propagation implications over Nigeria, especially the study of variation of radio field strength and radio horizon distance over few stations in
Nigeria [2,6]. This is not enough to generalise the variation of radio field strength and radio horizon distance over Nigeria, due to variation of meteorological parameters in each geographical location. Hence, this work studied the variation of radio field strength over seven locations in Nigeria covering the different climatic conditions. Two-year data of atmospheric variables: temperature, pressure and relative humidity obtained for Abuja, Akure, Jos, Lagos, Markurdi, Nsukka and Port-Harcourt locations were employed. The data were used to compute the surface radio refractivity which was then used to study the diurnal and seasonal, variability of radio field strength over Nigeria.

\section{VEGETATION ZONES IN NIGERIA}

Nigeria lies between latitudes $4^{\circ} \mathrm{N}$ and $14^{\circ} \mathrm{N}$ and longitude $3{ }^{\circ} \mathrm{E}$ and $15^{\circ} \mathrm{E}$, covering an area of about $924000 \mathrm{~km}^{2}$. The climate of Nigeria is broa dly equatorial and tropical continental. Movement of the Inter Tropical Discontinuity (ITD) complemented by aspects of ocean atmosphere coupling make Nigeria's climate truly tropical with generally high temperature ranging from $24^{\circ} \mathrm{C}$ to $27^{\circ} \mathrm{C}$ and annual mean temperature of $27^{\circ} \mathrm{C}$ in the tropical rainforest down south but higher mean value in the sub-Sahel up north. Tropical maritime air mass (South-Westerlies) and tropical continental air mass (NorthEasterlies) constitute the main wind system over the country. While the former fills the troposphere with moisture in the wet season, the latter brings a lot of Harmattan dust from the Sahara during the dry season. The characteristics of vegetation zones of the study locations are shown in Table 1.

Table 1. Characteristics of the vegetation zones of the study locations

\begin{tabular}{lllll}
\hline Locations & Latitude $\left({ }^{\circ} \boldsymbol{N}\right)$ & Longitude $\left({ }^{\circ} \boldsymbol{E}\right)$ & Elevation $(\mathbf{m})$ & Climate \\
\hline Abuja & 7.10 & 9.25 & 840 & Guinea Savannah \\
Akure & 7.25 & 5.21 & 396 & Tropical Maritime \\
Jos & 9.88 & 8.86 & 1217 & Sahel Savannah \\
Lagos & 6.30 & 3.20 & 41 & Monsoonal \\
Makurdi & 7.73 & 8.53 & 104 & Guinea Savannah \\
Nsukka & 6.90 & 7.67 & 552 & Tropical Rain Forest/Savannah \\
Port-Harcourt & 4.82 & 7.05 & 27 & Swampy \\
\hline \multicolumn{5}{r}{} \\
& & & Source: $[6,7]$ &
\end{tabular}



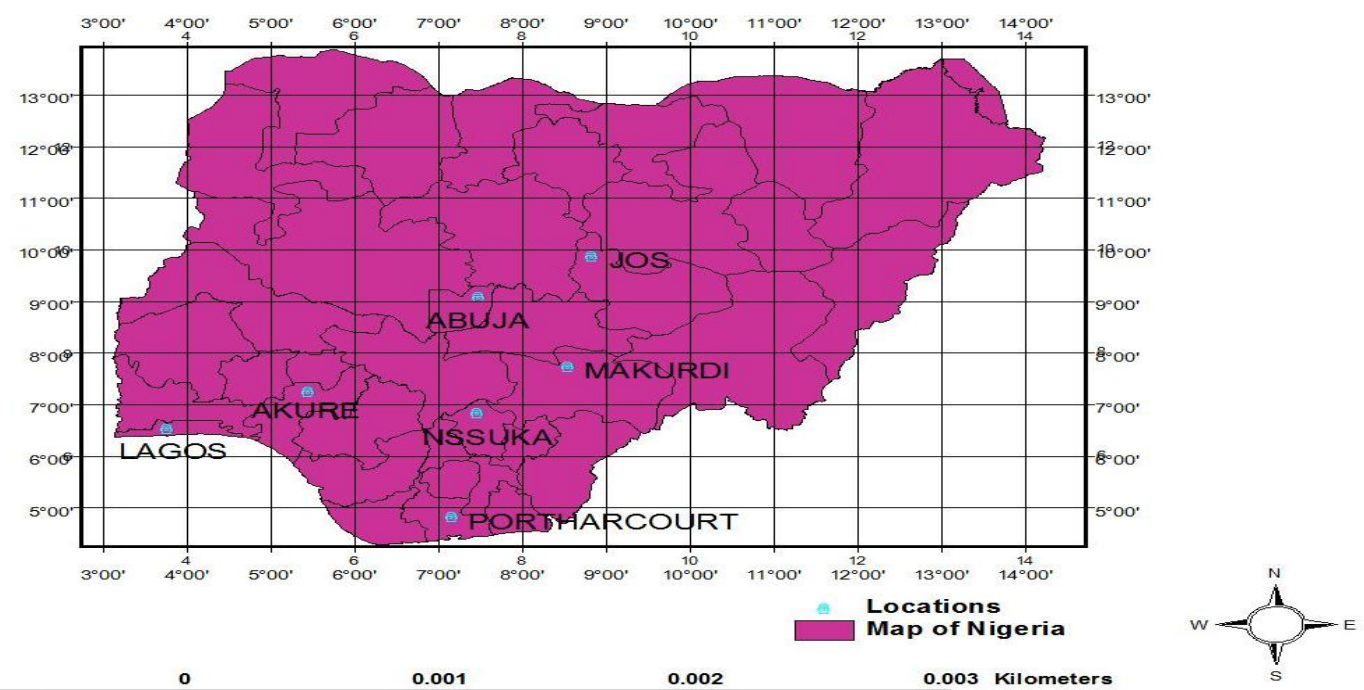

Fig. 1. Digitized map of Nigeria showing the study areas

The northern part of Nigeria experiences a long dry season (October to mid- May) followed by a short rainy season (June -September), during which annual mean is about $50 \mathrm{~cm}$. However, the southern part experiences a long rainy season (March-October) with maximum in June/July with a short dry period of about 2-3 weeks in August and a long dry season from mid- October to Early March. Annual mean along the South-Eastern Atlantic coast is about $400 \mathrm{~cm}$. These rainfall regimes endow Nigeria with two broad vegetation belts that comprise the forest to the south and the savannah to the north $[6,8]$. Above Fig. 1 shows the map of Nigeria indicating the locations considered for this study.

\section{INSTRUMENTATION}

The instrument used for the measurement of the atmospheric parameters used for this study is the wireless weather station shown in Fig. 2, which consists of a solar panel that converts the sun rays into electrical energy, a rain collector that measures the amount of rainfall and a tipping bucket rain gauge that measures the rain rate, sensors that measure temperature, pressure, relative humidity, UV index dose, solar radiation, and an anemometer that measures wind speed and direction. It is calibrated to measure the weather parameters in 5 minutes integration time. The data is stored in the data logger and then copied to a computer for analysis. The components of the Weather Station are shown in Fig. 3. The equipment was installed in all the locations considered for this study by the Centre for Atmospheric Research, (CAR) Anyigba,
Kogi State. The centre is one of the activity centres of the National Space Research and Development Agency, (NARSDA) in Abuja Nigeria. Tropospheric Data Acquisition Network (TRODAN) is a unit of CAR.

\section{THEORY AND METHODS}

Two-year (2011-2012) meteorological variables (pressure, temperature and relative humidity) were obtained from the archived data of Akure $\left(7.15^{\circ} \mathrm{N}, 5.12^{\circ} \mathrm{E}\right)$, Lagos $\left(6.30^{\circ} \mathrm{N}, 3.20^{\circ} \mathrm{E}\right)$, Abuja $\left(7.10^{\circ} \mathrm{N}, 9.25^{\circ} \mathrm{E}\right)$, Jos $\left(9.50^{\circ} \mathrm{N}, 8.50^{\circ} \mathrm{E}\right)$, Makurdi $\left(7.30^{\circ} \mathrm{N}, 8.53^{\circ} \mathrm{E}\right)$, Port-Harcourt $\left(4.20^{\circ} \mathrm{N}, 7.00^{\circ} \mathrm{E}\right)$, Nsukka $\left(6.90^{\circ} \mathrm{N}, 7.67^{\circ} \mathrm{E}\right)$. Each of the locations is equipped with complete wireless weather equipment as provided by Tropospheric Data Acquisition Network (TRODAN). The radio refractivity, $\mathrm{N}$ is related to radio refractive index and from the data collected, radio refractivity and field strength are computed $[9,10]$ as;

$$
N=(n-1) \times 10^{6}=\frac{776}{T}\left(p+\frac{4810 \times e}{T}\right)
$$

where $\mathrm{T}(\mathrm{K})$ is the air temperature, $\mathrm{P}(\mathrm{hPa})$ is air pressure and $\mathrm{e}(\mathrm{hPa})$ is water vapour pressure. Eq. (1) consists of two terms: the dry term and the wet term.

$$
\begin{aligned}
& N_{\text {dry }}=\frac{776 p}{T} \\
& N_{\text {wet }}=\frac{3.73 \times 10^{5}}{T^{2}} \mathrm{e}
\end{aligned}
$$


The dry term contributes about $70 \%$ to the total value of refractivity while the wet term is mainly responsible for its variability $[10,11,12]$.

Surface refractivity correlates highly with radio field strength, especially at the VHF bands. In the frequency range $30-300 \mathrm{MHz}$, a factor of $0.2 \mathrm{~dB}$ changes in field strength may be adopted for every unit change in $N_{s}[13,14]$. Using Ns values obtained in a given calendar month, maximum $\left(\mathrm{N}_{\mathrm{s}}(\max )\right)$, and minimum $\left(\mathrm{N}_{\mathrm{s}}(\min )\right)$ values of $\mathrm{N}_{\mathrm{s}}$ are determined, from which the monthly range is obtained as;

$$
\text { Monthly range }=\mathrm{N}_{\mathrm{S}(\max )}-\mathrm{N}_{\mathrm{s}(\min )}
$$

Thus, an assessment of field strength estimation (FSE) in a given location is explored from monthly ranges of $\mathrm{N}_{\mathrm{s}}$ using the relation;

$$
F S E=N_{S(\max )}-N_{s(\min )} \times 0.2 \mathrm{~dB} .
$$

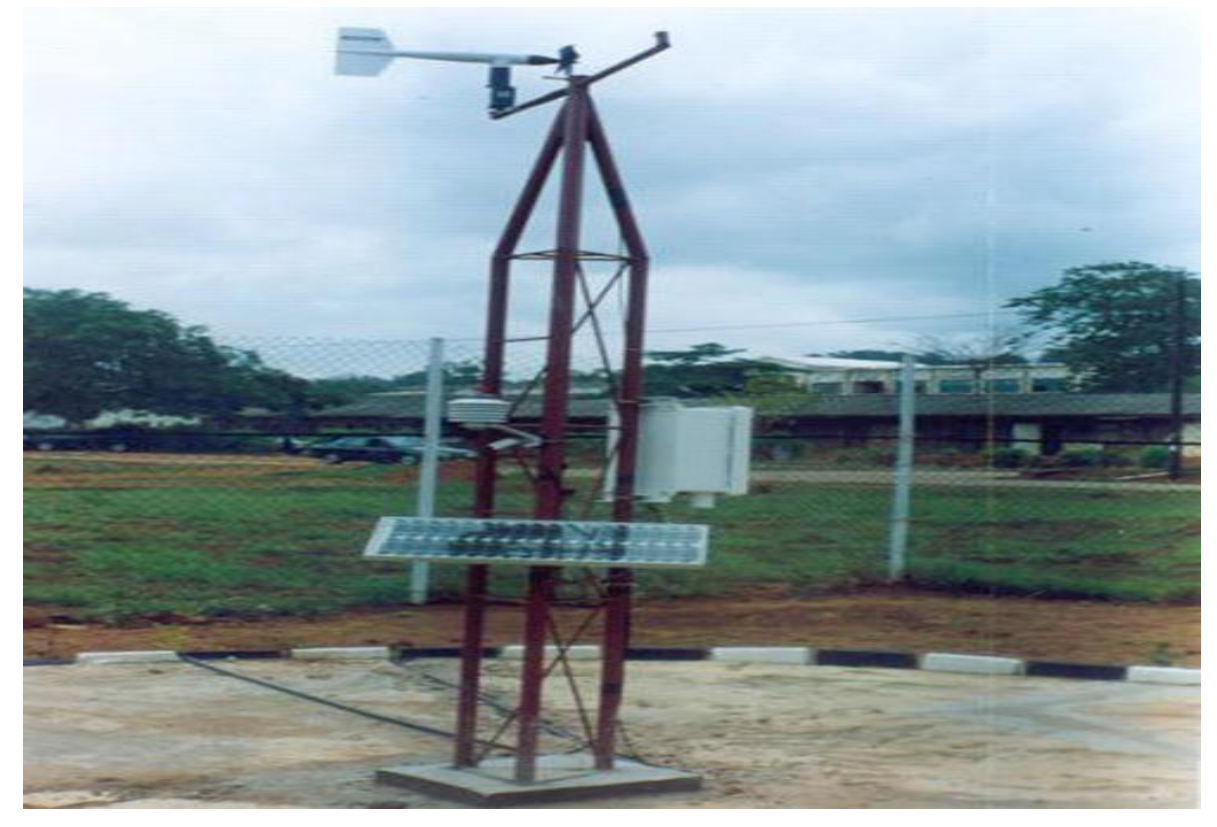

Fig. 2. Tropospheric data acquisition network (TRODAN) set up at a location

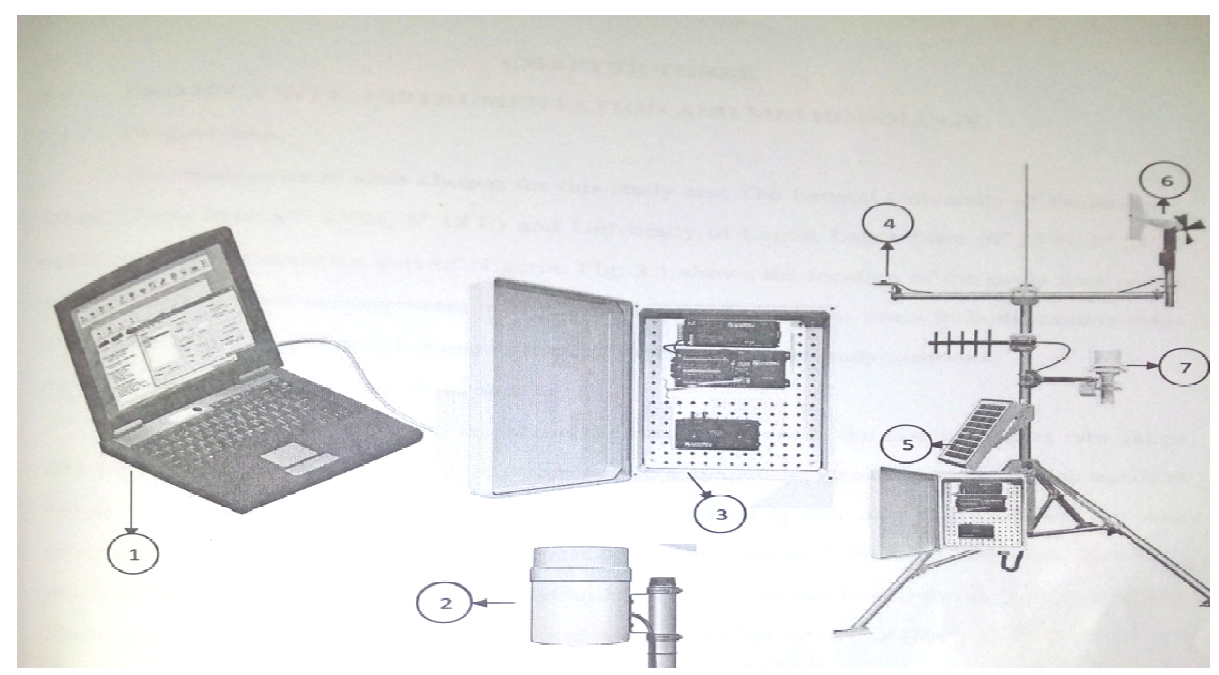

Fig. 3. A typical tropospheric data acquisition system components

Key: (1) Laptop, (2) Tipping bucket rain gauge, (3) CR100 data logger unit, (4) Pyranometer, (5) Solar panel, (6) Wind vane; and (7) Radiation shield 


\section{RESULTS}

\subsection{Diurnal Variation of Surface Refractivity of a Typical Day over the Stations}

Figs. 4-7 showed the diurnal variation of surface refractivity of a typical day over the stations.

\subsection{Seasonal Variation of Surface Refractivity over the Stations}

Figs. 8 and 9 showed the seasonal variation of surface refractivity over the stations.

\subsection{Seasonal Variation of Radio Field Strength over the Stations}

Figs. 10 and 11 showed the seasonal variation of radio field strength over the stations.

\subsection{Annual Variation of Surface Refractivity}

Table 2 showed the annual variation of surface refractivity.

\subsection{Annual Variation of Field Strength Variability}

Table 3 showed the annual variation of strength variability.

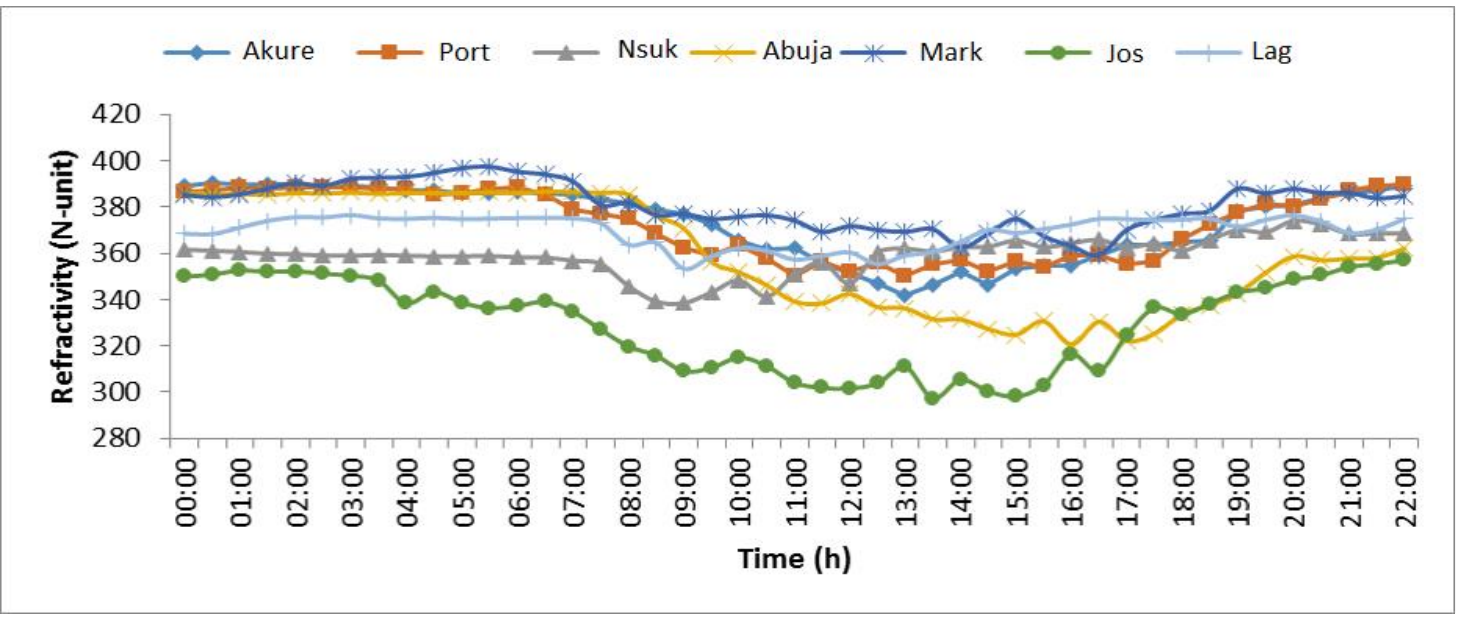

Fig. 4. Diurnal variation of surface refractivity for a typical day ( $1^{\text {st }}$ June) in wet season over all the stations for the year 2011

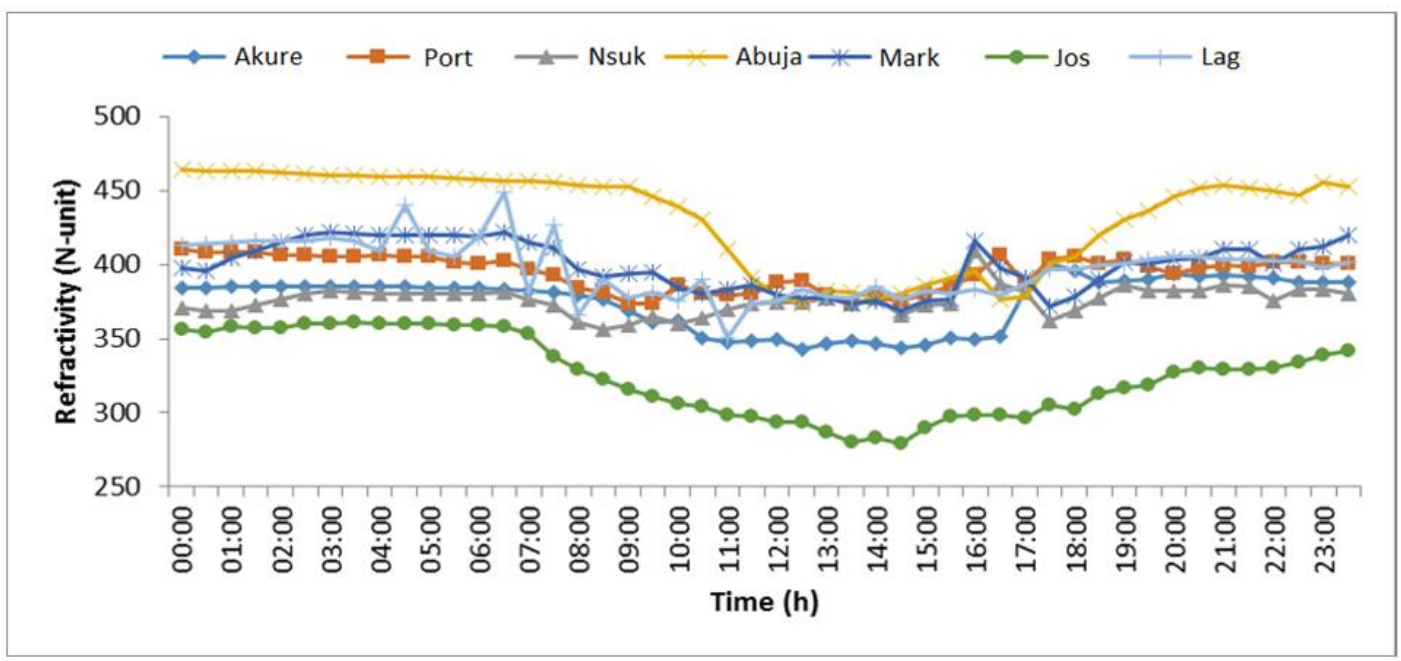

Fig. 5. Diurnal variation of surface refractivity for a typical day $\left(1^{\text {st }} \mathrm{June}\right)$ in wet season over all the stations for the year 2012 


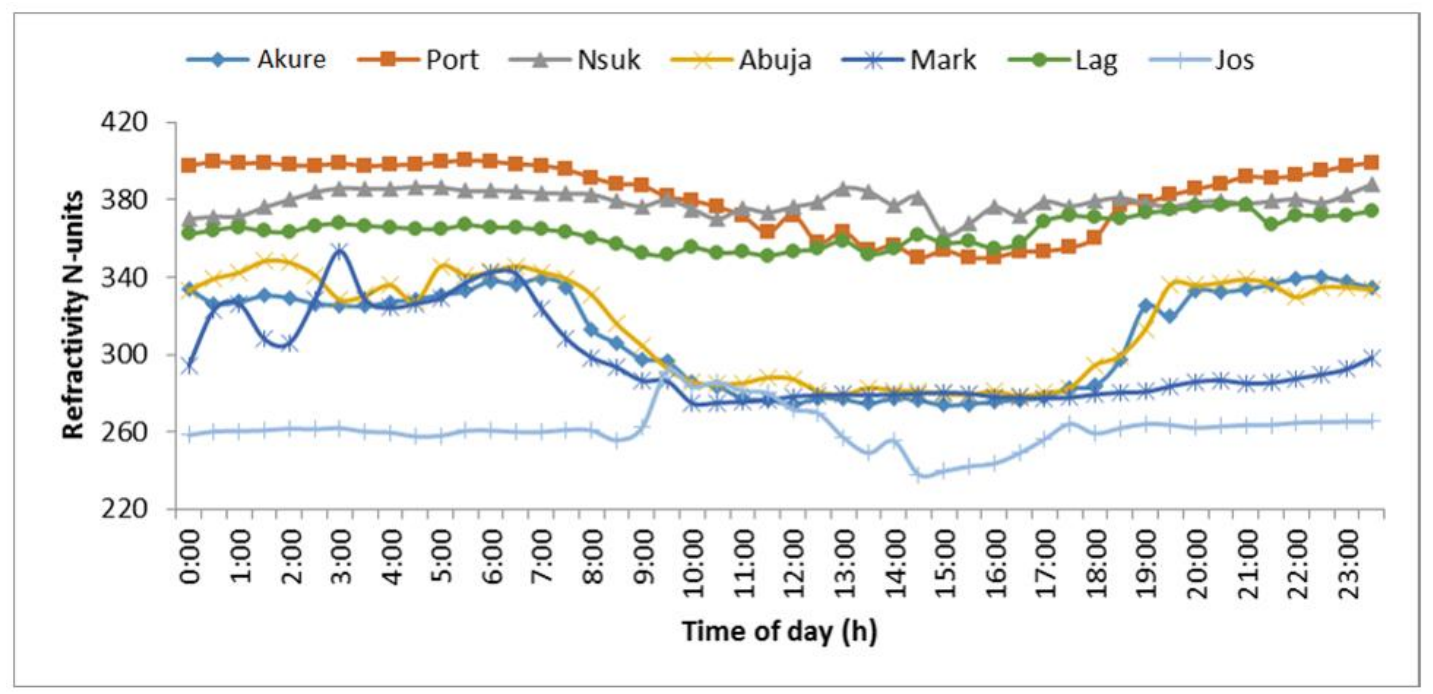

Fig. 6. Diurnal variation of surface refractivity for a typical day ( $1^{\text {st }}$ January) in dry season over all the stations for the year 2011

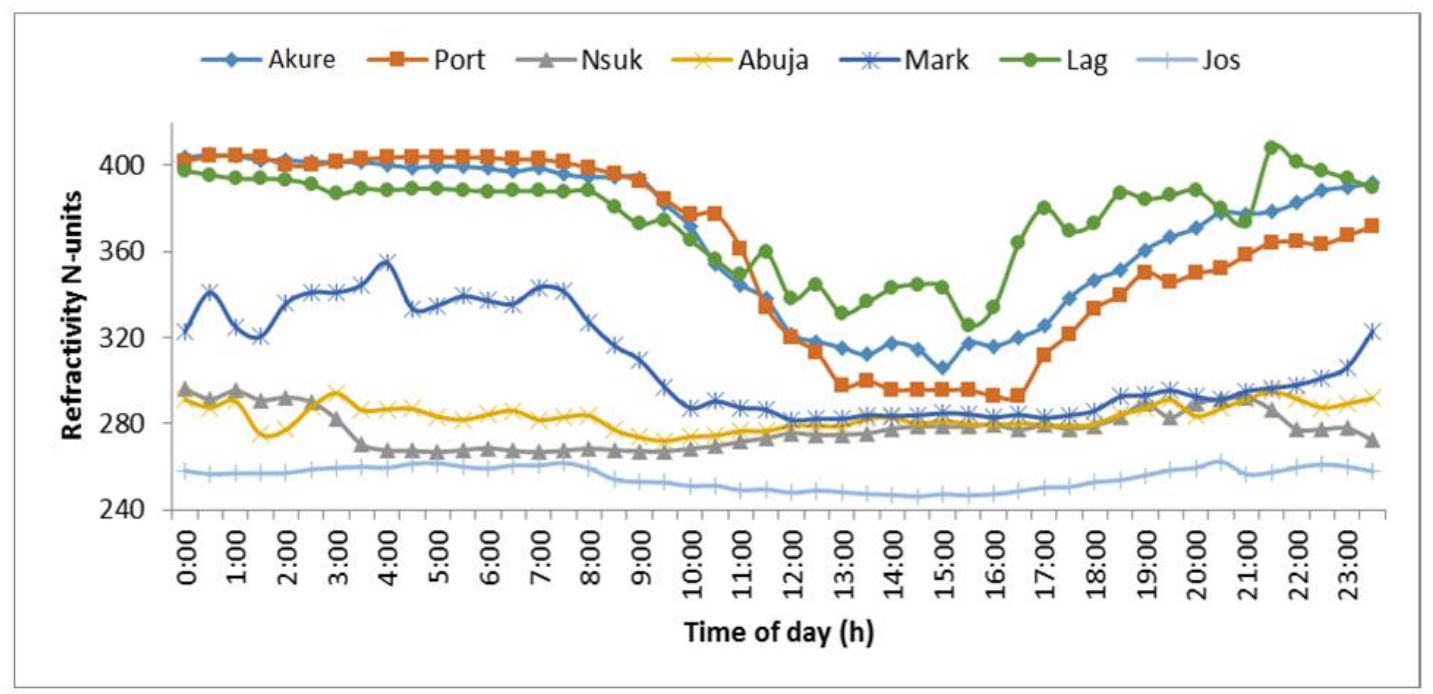

Fig. 7. Diurnal variation of surface refractivity for a typical day ( $1^{\text {st }}$ January $)$ in dry season over all the stations for the year 2012

Table 2. Annual variation of surface refractivity

\begin{tabular}{llll}
\hline Stations & $\mathbf{N}_{\mathbf{s}}$ (N-units) & $\begin{array}{l}\mathbf{N}_{\mathbf{s}} \text { (N-units) } \\
\mathbf{2 0 1 1}^{\mathbf{2 0 1 2}}\end{array}$ & Mean $\mathbf{N}_{\mathbf{s}}$ (N-units) \\
\hline Akure & 358.157 & 365.719 & 361.938 \\
Port-Harcourt & 394.747 & 404.061 & 399.404 \\
Nsuka & 358.090 & 365.752 & 361.921 \\
Makurdi & 362.177 & 387.824 & 375.001 \\
Abuja & 353.127 & 356.263 & 354.695 \\
Jos & 301.722 & 304.736 & 303.229 \\
Lagos & 390.480 & 391.244 & 390.862 \\
\hline
\end{tabular}




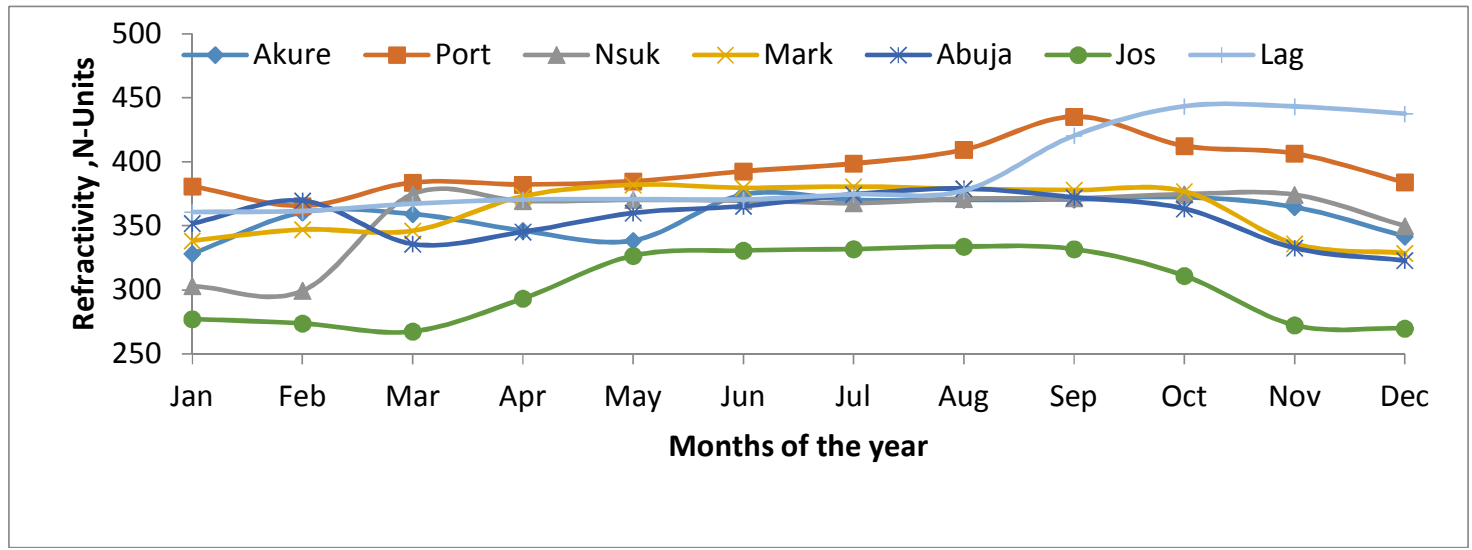

Fig. 8. Seasonal variation of surface refractivity over the stations for year 2011

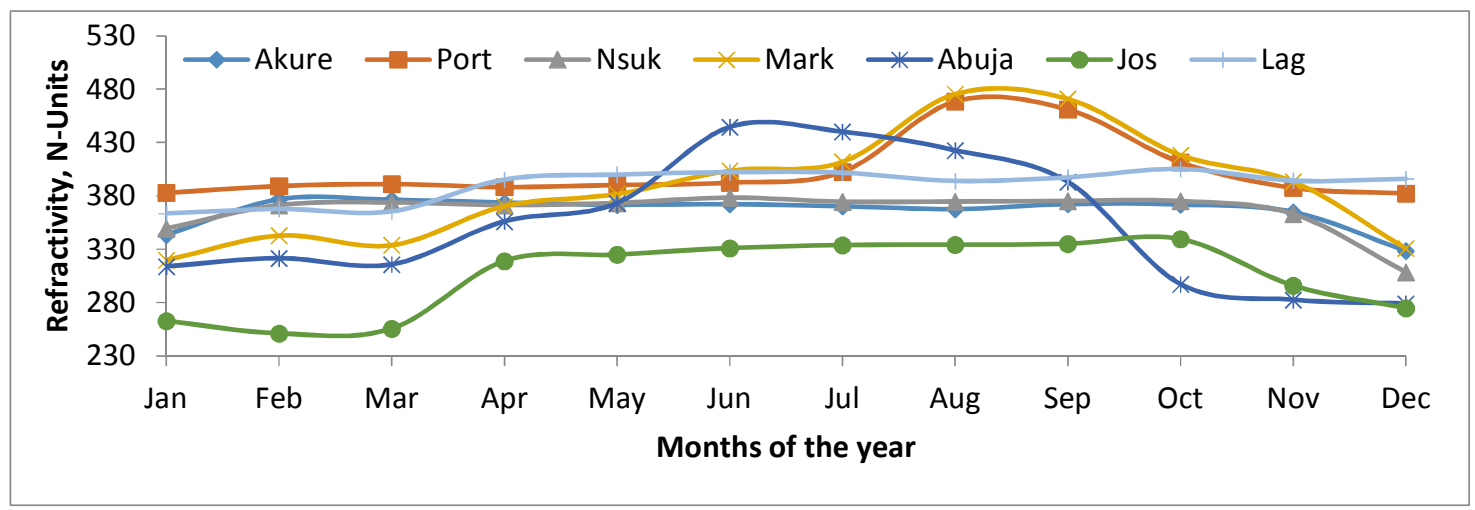

Fig. 9. Seasonal variation of surface refractivity over the stations for year 2012

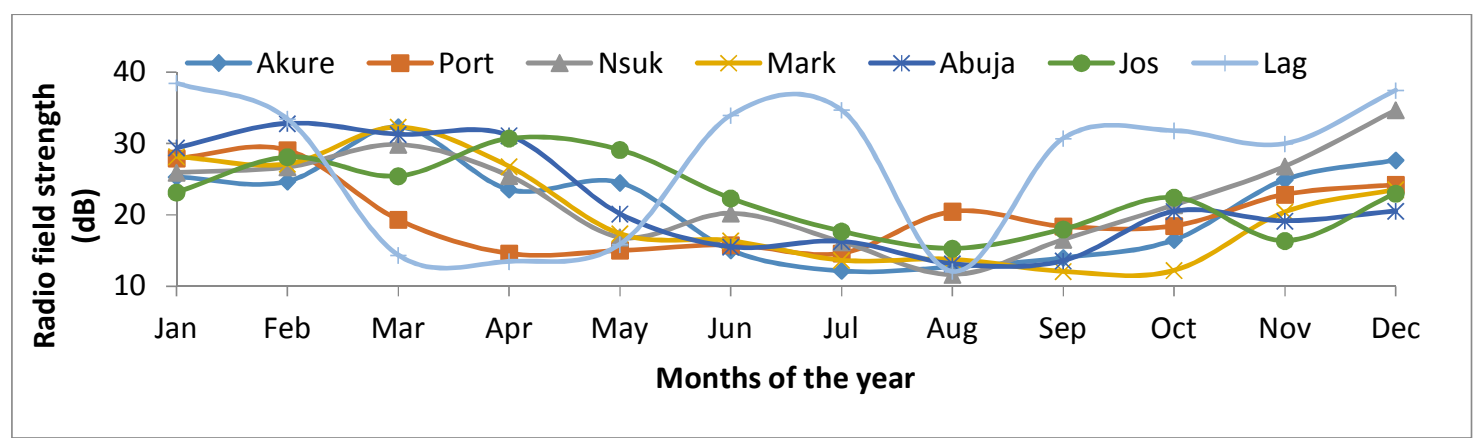

Fig. 10. Seasonal variation of radio field strength over the stations for the 2011

Table 3. Annual variation of field strength variability

\begin{tabular}{llll}
\hline Stations & FSV (dB) & FSV (dB) & Mean FSV (dB) \\
& $\mathbf{2 0 1 1}$ & $\mathbf{2 0 1 2}$ & \\
\hline Akure & 21.125 & 20.088 & 20.606 \\
Port-Harcourt & 20.069 & 23.688 & 21.879 \\
Nsuka & 22.691 & 20.288 & 21.489 \\
Makurdi & 20.330 & 28.290 & 24.310 \\
Abuja & 21.959 & 40.386 & 31.172 \\
Jos & 22.641 & 20.054 & 21.347 \\
Lagos & 27.187 & 21.244 & 24.216 \\
\hline
\end{tabular}




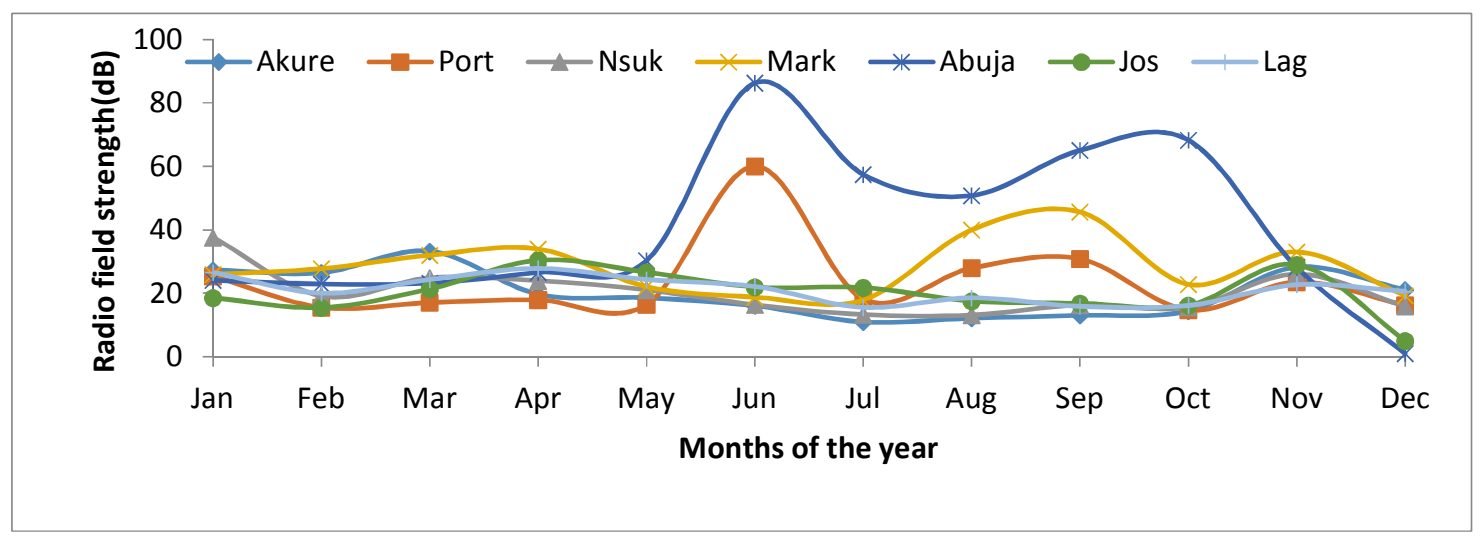

Fig. 11. Seasonal variation of radio field strength over the stations for the 2012

\section{DISCUSSION}

\subsection{Diurnal Variation of Surface Refractivity for a Typical Day over All the Stations}

The diurnal variation of surface refractivity over the stations is depicted in Figs. 4-7. It shows the average hourly time mean from 0:00 h. local time to 23:00 h. local time at the surface level for both the dry and the wet season months of years 2011-2012. As shown in Fig. 4, the surface refractivity has a high value of $400 \mathrm{~N}$-units to 323 $\mathrm{N}$ - units during the early hours of the day $(0.00-$ 7:00 $\mathrm{h}$. local time) and in the night hours (19:0023:00 h. local time) and starts reducing at 7:00 h. local time and reaches a minimum value of about $282 \mathrm{~N}$-units around 12:00 hr. local time in Jos. In Abuja, the surface refractivity shows a high value of about $369 \mathrm{~N}$-units to $374 \mathrm{~N}$ - units during the early hours $(0: 00-7: 00 \mathrm{~h}$. local time) of the day and late in the night (19:00-23:00 h. local time) and starts reducing at 7:00 hr. local time and also increases a little at 12:00 h. local time to about $338 \mathrm{~N}$ - units and drops again to a minimum value of $322 \mathrm{~N}-$ units at 13:00 h. local time. Furthermore, in Nsuka surface refractivity shows a high value of $356 \mathrm{~N}$ - units to $362 \mathrm{~N}$ - units during the early hours of the day $(0: 00-7: 00 \mathrm{~h}$ local time) and late in the night (19:00-23:00 hr. local time) and starts dropping at 7:30 hr. local time and reaches a minimum of about $331 \mathrm{~N}$ units at around 15:30 h. local time. Moreover, in Markurdi a high value surface Refractivity of about $389 \mathrm{~N}$ - units to $373 \mathrm{~N}$-units is shown during the early hour of the day $(0: 00-6: 00 \mathrm{~h}$. local time) and late in the night (19:00-23:00 h. local time) and starts reducing at $6: 30 \mathrm{~h}$. local time and reaches a minimum value of $340 \mathrm{~N}$ units at 15:30 h. local time. In Akure, the surface refractivity value is $374 \mathrm{~N}$-units at the early hours of the day (0:00-6:00 hr. local time) and increases to $375 \mathrm{~N}$-units at 7:00 hr. local time and starts dropping at 7:30 hr. of local time and reaches a minimum value of $330 \mathrm{~N}$-units at 15:30 hr. of local time. It also shows that in PortHarcourt, the surface refractivity value increases from $405 \mathrm{~N}$ units in the early hour of the day $(0: 00 \mathrm{~h}$. local time) to $410 \mathrm{~N}$-units at 7:00 h. local time and starts dropping at 7:30 $\mathrm{h}$. local time and reaches a minimum value of $377 \mathrm{~N}$-units at 12:30 h. local time. In Lagos, the surface refractivity value at the early hours of the day $(0: 00 \mathrm{~h}$. local time $)$ is $390 \mathrm{~N}$-units and $391 \mathrm{~N}$ units at $6: 30 \mathrm{~h}$. local time and starts reducing to a minimum value of $361 \mathrm{~N}$-units at 14:30 h. local time, Also the diurnal variation of surface refractivity shows the same trend in year 2012. Refractivity values are generally high in the early and late hours of the day; the values starts to drop at about 7:30 h. The minimum value is observed around 15:30 h. local time after which the values rise till the end of the day except in Nsukka in year 2011 where there is change in the trend of the curve and this is attributed to the influence of the local meteorology on the area. This variation can be attributed to the response of the earth solar insolation which is the major forcing behind the weather condition observed. The results compare favourably well with the work of [15] where they observed in Nigeria that the diurnal surface refractivity is a function of local meteorology.

It was shown that the diurnal variation of surface refractivity for a typical day in years 2011-2012 varied with high values of surface refractivity in the early hours in the morning and late night and very low between 11:00 LT-16:30 LT for both the dry and wet season. For $1^{\text {st }}$ June (wet season) of the both years, it recorded very high values surface refractivity due to high humidity and low 
temperature in the troposphere while $1^{\text {st }}$ January dry (dry season) of both years showed the same trend of curve with the wet season but recorded low values of surface refractivity due to high temperature and low humidity in the troposphere.

\subsection{Seasonal Variation of Surface Refractivity over the Stations}

Figs. 8 and 9 showed the seasonal variation of refractivity for the study areas over the periods of two years (2011-2012) considered for this study. It is observed from that the result agreed with the works of $[14,15,16,17]$. There is seasonal variation of surface refractivity at all the stations studied, an increase in the value of refractivity from minimum value of about $250.9 \mathrm{~N}$-units at Jos station to maximum value of about $469 \mathrm{~N}$ units in Port-Harcourt. This result compares favourably well with the works of $[9,15]$, where they obtained $270 \mathrm{~N}$-units as a minimum value of surface refractivity in Sokoto and $390 \mathrm{~N}$-units as the maximum value in Lagos. It can also be seen that in 2011, Lagos has the maximum value of refractivity of $436 \mathrm{~N}$ - units in December which is expected to be low. This is due to the influence of the Atlantic Ocean on the station and also high humidity and water vapour. Jos has the minimum value of refractivity $269 \mathrm{~N}$-units in December. In 2012, Port-Harcourt has the maximum value of refractivity of $468 \mathrm{~N}$-units in August. The mean value of surface refractivity for the stations, Akure, Lagos, Abuja, Markurdi, Port-Harcourt, Jos and Nsukka for the two years are $361.86 \mathrm{~N}$ units, $390.87 \mathrm{~N}$-units, $354.74 \mathrm{~N}$-units, $371.41 \mathrm{~N}$ units, $396.91 \mathrm{~N}$-units, $323.76 \mathrm{~N}$-units and 360.35 $\mathrm{N}$-units. The result of Akure station compares favourably well with the works of $[18,19]$ where they obtained mean value of surface refractivity for five years to be $364.74 \mathrm{~N}$ - units and $369 \mathrm{~N}$ units respectively. Similarly, [20] obtained a mean value of surface refractivity of $365 \mathrm{~N}$-units and $367 \mathrm{~N}$-units for years 2007 and 2008 respectively over Akure. It is seen from the results of the mean value of surface refractivity that Jos have a very low value of refractivity. This may be due to the altitude which is $\sim 1217 \mathrm{~m}$ above sea level. At this altitude pressure variation seems insignificant. It is also shown from Figs. 4 and 5 that the value of refractivity depicted seasonal variation with high value during the rainy season and low value during the dry season. It is also shown that the surface refractivity has high value at the coastal areas compared with the inland areas. This is due to the influence of the Atlantic Ocean on the coastal areas. This result supports the work of [21]. This result is in agreement with the result obtained by [22] which was produced as world atlas for refractivity variation.

\subsection{Seasonal Variation of Radio Field Strength over the Stations}

The seasonal variation of radio field strength over the stations for the two years (2011-2012) is shown in Figs. 10 and 11 respectively. As shown in Fig. 10, it is observed that radio field strength for Lagos and Port-Harcourt are out of phase with that of Akure, Abuja, Nsukka, Markurdi and Jos in March. Lagos is also out of phase with Markurdi, Port-Harcourt and Akure in October. It is also seen that the radio field strength is high during the dry season months from November to March and low during the wet season months from March to October, except for Lagos that showed a very high value of $33.93 \mathrm{~dB}$ in June and $34.69 \mathrm{~dB}$ in July. This may be attributed to the influence of the local meteorology on the area which is due to the response of the earth solar insolation which is the major forcing behind the weather condition observed. In Fig. 11, it is seen that the radio field strength shows an irregular oscillations where it is high in January and dropped slightly in December. Abuja has a high value of $86.33 \mathrm{~dB}$ in June and Port-Harcourt shows a high value of $60.11 \mathrm{~dB}$ in June. The annual mean of radio field strength in Abuja, Akure, Jos, Lagos, Markurdi, Nsukka and portHarcourt is $30.28,20.61,21.39,24.21,24.31$, 21.49 and $21.48 \mathrm{~dB}$ respectively. The difference in radio field strength variation between Northern and Southern Nigeria is affected by other factors such as scattering by dust plumes, which will affect the Northern part mostly in the dry season. From the observed field strength variability in Abuja, Lagos, Jos, Markurdi, Akure, PortHarcourt and Nsukka, the output of a receiving antenna in all the locations may generally be subjected to variations of not less than 15.53 , $12.09,15.30,12.11,12.17,14.59$ and $11.62 \mathrm{~dB}$ respectively in 2011, but can be as high as $38.45,30.72$ and $34.67 \mathrm{~dB}$ in January, April and December over Lagos, Jos and Nsukka respectively. In Akure and Markurdi, the corresponding values in March are 32.32 and $32.29 \mathrm{~dB}$ while in Abuja and Port-Harcourt, are 32.80 and $29.06 \mathrm{~dB}$ in February. In Fig. 11, the radio field strength variability of an output of a receiving antenna in Akure, Abuja, Lagos, Jos, Markurdi, Port-Harcourt and Nsukka is not less than $10.94,1.05,15.60,5.01,17.90,14.78$, and $13.15 \mathrm{~dB}$ and can be as high as $33.22 \mathrm{~dB}$ in March over Akure, $30.43 \mathrm{~dB}$ in April over Jos, 
$45.66 \mathrm{~dB}$ in September over Markurdi, 37.61 and $27.85 \mathrm{~dB}$ over Lagos and Nsukka in January and 60.11 and $86.33 \mathrm{~dB}$ over Port-Harcourt and Abuja. The annual variations of a receiver output in Akure, Abuja, Lagos, Jos, Markurdi, PortHarcourt and Nsukka in June is 16.47, 86.33, $22.15,21.94,18.80,60.11$ and $16.41 \mathrm{~dB}$ respectively. Thus, identical systems in Akure, Abuja, Lagos, Jos, Markurdi, Port-Harcourt and Nsukka have outputs differing by as much as $5.53,85.28,6.55,16.93,0.90,45.33$ and $3.26 \mathrm{~dB}$ respectively in June. The knowledge of this radio field strength trends will enhance good assessment of field performance to ensure increased reliability of existing or planned terrestrial radio link over Nigeria.

\subsection{Annual Variation of Surface Refractivity $\mathbf{N}_{\mathrm{s}}$ and Radio Field Strength over all the Stations for Years 2011-2012}

The average values of $\mathrm{N}_{\mathrm{s}}$ and radio field strength over the stations for the two years (2011-2012) are shown in Tables 2 and 3 respectively. It is observed from the table that in year 2011, the average $\mathrm{N}_{s}$ values over the stations, Akure, Abuja, Port-harcourt, Nsuka, Makurdi, Jos and Lagos are 358.157, 353.127, 394.747, 358.090, $362.177, \quad 301.722$ and $390.480 \quad \mathrm{~N}$-units respectively and in year 2012 , the average $N_{s}$ values over the stations, Akure, Abuja, Portharcourt, Nsuka, Makurdi, Jos and Lagos are 365.719, 356.263, 404.061, 365.758, 387.824, 304.736 and $391.244 \mathrm{~N}_{\mathrm{s}}$-units respectively. It is also observed that the average values of $\mathrm{N}_{\mathrm{s}}$ were higher in year 2012 than year 2011. This may be attributed to high humidity in the troposphere in year 2012 than year 2011. It is shown that PortHarcourt and Lagos have the highest average values of $\mathrm{N}_{\mathrm{s}}$ of $399.404 \mathrm{~N}$-units and $390.864 \mathrm{~N}$ units respectively while Jos has the lowest average value of $\mathrm{N}_{\mathrm{s}}$ of $303.229 \mathrm{~N}$-units. The field strength variability showed that Abuja has the highest average value of $31.172 \mathrm{~dB}$ and Akure has the least value of $20.606 \mathrm{~dB}$. The differential field strength variation between the Northern (Abuja) and Southern (Akure) Nigeria is affected by other factors like scattering by dust which will affect the Northern part mostly during dry season.

\section{CONCLUSIONS}

Two-year (Jan. 2011-Dec. 2012) archived data of atmospheric variables: temperature, pressure and relative humidity obtained for Abuja, Akure,
Jos, Lagos, Markurdi, Nsukka and Port-Harcourt locations were employed in this study. The data were used to compute the surface radio refractivity which was then used to study the diurnal and seasonal, variability of radio field strength. However, the main findings in the study are as follows: The surface refractivity were high at the early hours of day and very low between the hours of 12:00 LT and 16:00 LT and also high at late night in all the locations for this study. Surface refractivity value over Nigeria increases from about $250.9 \mathrm{~N}$-units in the Northern part to about $469 \mathrm{~N}$-units in the Southern part. Seasonal surface refractivity shows a seasonal variation with high values in the wet season months and low values in the dry season months over Nigeria. The mean surface refractivity value was highest in Port-Harcourt with $404 \mathrm{~N}$-units and lowest in Jos with $302 \mathrm{~N}$ - units. The difference in the values of the surface refractivity over Nigeria is attributed to the meteorological influence of the semi- permanent climatological features, such as ITD, Sub-Tropical High Pressure (STHP) and associated monsoonal flow pattern. The FSV values were low during the wet season months and high during the dry season months over Nigeria except in Abuja, Lagos and PortHarcourt.

\section{ACKNOWLEDGEMENTS}

The authors are grateful to the communication research group of Physics Department, Federal University of Technology, Akure. The Centre for Basic Space Studies of the National Space Research Development Agency (NARSDA).

\section{COMPETING INTERESTS}

Authors have declared that no competing interests exist.

\section{REFERENCES}

1. Adediji AT, Ajewole MO. Vertical profile of radio refractivity gradient in Akure South-West Nigeria. Progress in Electromagnetics Research C. 2008;4:157168.

2. Freeman RL. Radio system design for telecommunications ( ${ }^{\text {rd }}$ Ed.). New York: Wiley-Inter-Science; 2007.

3. Harada H, Fujise M. Research on mobile communications in microwave and millimetre-wave frequency ranges at CRL. Wireless Personal Communications. 2003; 26:117-133. 
4. Asif IQBAL, Varun JEOTI. An improved split-step wavelet transform method for anomalous radio wave propagation modeling. Radioengineering. 2014;23(4): 987-996.

5. Zhihua LAI, Guillaume De La Roche, Nik Bessis, Pierre Kuonen, et al. Intelligent ray launching algorithm for indoor scenarios. Radioengineering. 2011;20(2): 398-408.

6. Adediji AT, Ismail M, Mandeep JS. Performance analysis of microwave radio refractivity on radio field strength and radio horizon distance over Akure, Nigeria, Wireless Personal Communications. 2014a;77:4. ISSN: 0929-6212

7. Ojo JS, Adediji AT, Mandeep JS, Ismail M. Variation of slant path $\mathrm{Ka} / \mathrm{V}$ band rain attenuation over seven tropical locations in Nigeria using synthetic storm techniques. Journal of Theoretical and Applied Climatology. 2015;120:1-2.

8. Umoh TU. Rainfall characteristics and agricultural planning in Northern Nigeria. Nigerian Journal of Teacher's. Geography. 2:48-54.

9. Kolawole LB. Climatological variations of surface radio refractivity in Nigeria. Bulletin of Nigerian Institute of Physics. 1980;4:97117.

10. Daniela Řezáčová, Ondřej Fišer, Ramón Sáez Lucas. Statistics of radio refractivity derived from Prague radiosounding data. Radioengineering. 2003;12(4):84-88.

11. Grábner $M$, Kvičera $V$. Refractive index measurement at TV tower Prague. Radioengineering. 2003;12(1):5-7.

12. Babin SM, Young GS, Carton JA. A new model of the oceanic evaporation duct. Journal of Applied Meteorology. 1997;36: 193-204.
13. ITU-R. The refractive index: Its formula and refractivity data. 2003;453-9.

14. CCIR, Report. Los-Angeles. 1959;147.

15. Owolabi IE, Williams VA. Surface radio refractivity patterns in Nigeria and the Southern Cameroon. Journal of West African Science Association. 1970;1:3-17.

16. Ayantunji BG, Okeke PN, Urama JO. Diurnal and seasonal variation of surfacerefractivity over Nigeria. Progress in Electromagnetic Research B. 2011;30: 201-222.

17. Oyedum OD, Gambo GK. Surface radio refractivity in Northern Nigeria. Nigerian Journal of Physics. 1994;6:36-41.

18. Žilinskas $M$, Tamošiu nas $S$, Tamošiu naite $M$, Tamošiu ñene $M$. Yearly seasonal and daily variations of radio refractivity. Physical Aspects of Microwave and Radar Applications. 2011; 119(4):423.

19. Adediji AT, Ismail M, Mandeep JS. Performance analysis of microwave radio refractivity on radio field strength and radio horizon distance over Akure, Nigeria. Wireless Personal Communications. 2014b;77:4.

ISSN: 0929-6212

20. Falodun SE, Ajewole MO. Radio refractive index in the lowest $100 \mathrm{~m}$ layer of the troposphere in Akure, South-Western Journal of Atmospheric and Solar terrestrial Physics. 2006;68:236-243.

21. Dhein NR, Pontes MS, Silva ML. Statistical Behaviour of refractivity gradient in the tropics. IEEE Conference Publication. 1993;3.

22. Adediji AT, Ajewole MO. Variation of radio refractivity gradient and effective Earth radius factor (K-factor) over Akure, Southwestern Nigeria. IEEE; 2011. 978-1-4244$51180 / 11$

(c) 2017 Adediji et al.; This is an Open Access article distributed under the terms of the Creative Commons Attribution License (http://creativecommons.org/licenses/by/4.0), which permits unrestricted use, distribution, and reproduction in any medium, provided the original work is properly cited.

Peer-review history:

The peer review history for this paper can be accessed here: http://sciencedomain.org/review-history/19063 